\title{
Cloning and Over Expression of CVS Rabies Virus Glycoprotein Gene in Pichia pastoris by Multimeriztion
}

\author{
T.M. Ningaraju ${ }^{1 *}$ and P.H. Ramanjini Gowda ${ }^{2}$ \\ ${ }^{1}$ Department of Biotechnology, College of Sericulture, Chintamani, UAS(B), Karnataka, India \\ ${ }^{2}$ Department of Biotechnology, University of Agricultural Sciences, \\ Bangalore, Karnataka, India \\ *Corresponding author
}

\section{A B S T R A C T}

\section{Keywords}

Glycoprotein gene;

Pichia pastoris;

CVS Rabies Virus,

SDS-PAGE: RT-

PCR

Article Info

Accepted:

12 November 2018

Available Online:

10 December 2018
Rabies is an endemic, fatal zoonotic disease which is transmitted by the bite of an infected animal. The glycoprotein of rabies virus is most antigenic and immunogenic determinant present in rabies virion and can serve as effective target for development of vaccine. The CVS rabies glycoprotein gene (1575 bp) was cloned into cloning vector $\mathrm{pTZ57R/T}$ and confirmed by PCR and Sequencing, further the glycoprotein gene was sub cloned into yeast integrative vector pPICZ $\alpha \mathrm{A}$ for expression and over expressed by using pPIC9K vector. Linearised recombinant vector containing glycoprotein gene was introduced into Pichia pastoris (GS115 and X-33) by electrophoration and the recombinant yeast clones were identified by PCR analysis. The recombinant protein expressed in yeast was confirmed by SDS-PAGE, ELISA, western blot and over expression was confirmed RTPCR. These results allow us to conclude that $P$. pastoris is a convenient system for expression as well as for over expression of CVS rabies glycoprotein through multimeriation.

\section{Introduction}

Rabies is a widespread disease and constantly producing victims in human beings as well as in domestic and wild animals in many countries. Presently, however, human rabies cases are reported mostly from developing countries (totally 30,000 persons or more are estimated to die of rabies every year (Meslin et al., 1994). The rabies is unique for its peculiar disease symptoms (e.g. fear of water, painful spasms of the throat triggered by swallowing, etc.) and still is a fearful disease of high mortality rate (almost 100 per cent). Rabies is not only a public health problem in epidemic areas, but also causes serious economical loss due to outbreaks in cattle of livestock farming in Latin American countries (Arellano-Sota, 1988; Escobar-Cifentes, 1998).

Rabies virus belongs family, Rhabdoviridae, order, Mononegavirales and genus Lyssa virus. The primary structure of the 3' half of rabies viral genome, present in order, the genes encoding for $(+)$ leader RNA, the nucleoprotein ' $\mathrm{N}$ ', the phosphoprotein 'M1', the matrix protein 'M2', the glycoprotein ' $\mathrm{G}$ ' and the beginning of the larger protein ' $\mathrm{L}$ ' which is an essential component of the rabies 
virus RNA dependent RNA polymerase (Kawai, 1977). The native $G$ protein is 524 amino acids long, consisting of 19-residue long signal peptide at $\mathrm{N}$-terminus (Anilionis et al., 1981), a 22 amino acid transmembrane domain and a 44 amino acid c Anilionis ytoplasmic domain (Wunner et al., 1983). Glycosylation of the $G$ protein is required for immune protection by the rabies vaccines (Foley et al., 2000).

Rabies vaccines currently used in the developed countries are purified killed virus, which are produced from the infected tissue culture materials. Human diploid cell rabies vaccines have been given to more than 1.5 million people worldwide as of 2006. Newer and less expensive purified chick embryo cell vaccine and purified Vero cell rabies vaccine are now available. The purified Vero cell rabies vaccine uses the attenuated Wistar strain of the rabies virus, and uses the Vero cell line as its host. To control rabies in the dogs, oral immunization is being carried out with live attenuated vaccines, modified live virus rabies vaccine, recombinant rabies vaccine in baits. These vaccines though used extensively, suffer from certain flaws such as requirement of cold chain, administration within $24 \mathrm{~h}$. of infection and their high cost. The recombinant rabies virus glycoprotein (rRVGP) has been produced in several expressions systems: [transgenic plants (Ashraf et al., 2005), yeast cells (Sakamoto et al., 1999), mammalian cells (Kankanamage et al., 2003), and insect Sf9 cells infected with Baculovirus (Drings et al., 1999)].Yeast is one of the eukaryotic microbes that was used for producing viral antigens because of their ability to produce the glycosylated form of the antigens. Within the past 15 years Pichia pastoris has successfully entered the scene and is now the second most used host for recombinant gene expression. Based on searches of the PubMed citation database, the use of $P$. pastoris as an expression host has increased from 4per cent to 17 per cent of the total recombinant genes reported from 1995 to 2009 (Sorensen, 2010),

Optimization of protein expression is often, but not always, includes the isolation of multicopy expression strains. A strain that contains multiple integrated copies of an expression cassette can sometimes yield more heterologous protein than single-copy strains (Thill et al., 1990; Clare et al., 1991). Strains that contain multiple integrated copies of an expression cassette often produce larger amounts of foreign protein than do singlecopy strains (Clare et al., 1991). Therefore, after confirming that a single-copy $P$. pastoris strain produces significant amounts of the correct-sized, biologically active protein, it is advisable to construct and examine protein expression by "multicopy strains" (Li et al., 2007). There are three different approaches that can be used reliably to generate multicopy expression strains of $P$. pastoris. The first approach involves constructing a vector with multiple head-to-tail copies of an expression cassette (Brierley et al., 1998). The second approach entails the use of an expression vector that contains both the P. pastoris HIS4 and the bacterial kanamycin resistance gene kanR, which also confers resistance to the related eukaryotic antibiotic G418 (Scorer et al., 1994). The third approach involves the use of a vector carrying the bacterial Sh ble gene, which confers resistance to the antibiotic zeocin (Higgins et al., 1998). A detailed description of these methods can be found in Higgins and Cregg (Higgins and Cregg, 1998). Multicopy expression strains of all three types have proven to be stable under the selective pressure of production in fermentor cultures (Higgins et al., 1998).

Mansur et al., (2005) followed two consecutive approaches to increase the number of integrated cassettes: the head-to-tail expression cassette multimerization procedure 
and re-transformation with a dominant selection marker. This increased expression from 19 to $250 \mathrm{mg} / \mathrm{l}$ when about 11 copies have been integrated. Keeping this in view, the present study was taken to produce and over express the CVS rabies virus Glycoprotein in Pichia pastoris.

\section{Materials and Methods}

\section{Isolation of CVS rabies glycoprotein gene}

Total RNA was isolated from cell line BHK21 infected with CVS rabies virus (obtained from NIMHANS) using RNeasy mini kit (Qiagen company, GmbH, Germany) and gene specific cDNA by RT-PCR using Omniscript Reverse transcriptase (Qiagen company, $\mathrm{GmbH}$, Germany). Total RNA isolation and Reverse transcriptase PCR reaction were done as per the manufacturer's instructions. RNA so isolated was quantified using a spectrophotometer at $260 \mathrm{~nm}$.

The RNA samples were diluted to $1 \mu \mathrm{g} / \mu \mathrm{l}$ concentration using DEPC treated water. $1 \mu \mathrm{g}$ total RNA was used for getting a gene specific cDNA. The procedure does not allow sample cross contamination and cDNA is utilized as a template for the PCR step, For amplifying full length gene of glycoprotein using specific primers.

\section{Cloning of PCR product}

The purified PCR amplicon of CVS glycoprotein was ligated to pTZ257R/T cloning vector (2868 bp), as described in InsT/A cloneTM PCR product cloning kit (K1214) of MBI, Fermentas, USA. For ligation, an optimal molar ratio of 1:3 vector: insert was calculated. The ligation mixture along with linerised vector and amplicon DNA were mixed in $0.5 \mathrm{~mL}$ micro-centrifuge tubes and incubated at $16^{\circ} \mathrm{C}$ for $16 \mathrm{~h}$. for ligation.
Preparation of competent cells and Transformation of $E$. coli DH5a

The competent cells of E. coli DH5 were prepared by following the protocol mentioned by Sambrook and Russell (2001) with minor modifications. About 100ul of freshly prepared competent cells were taken in a chilled centrifuge tube and 10:1 of ligation mixture was added and mixed gently. The mixture was chilled in ice for $45 \mathrm{~min}$ and heat shock was given by shifting the chilled mixture to preheated $42^{\circ} \mathrm{C}$ water bath for exactly $2 \mathrm{~min}$.It was immediately transferred to ice to chill for $5 \mathrm{~min}$. The culture was pre incubated and spread on the plates having Luria agar with Amp50, X-gal, IPTG and incubated overnight at $37^{\circ} \mathrm{C}$. The recombinant clones were identified by blue/white assay.

\section{Confirmation of clones by PCR and by sequencing}

The Confirmation of the presence of cloned insert was done by PCR amplification of recombinant vectors with respective primers. The total DNA and cloning vector were used as positive and negative controls in the process. The full length $1.575 \mathrm{~kb}$ of CVS glycoprotein gene amplicon cloned in pTZ257R/T was sequenced using M13 primers walking technique at Chromas Private Ltd., Bangalore. The sequences were subjected to analysis using BLAST algorithm available at http://www.ncbi.nim.nih.gov.

Sub cloning of the cloned CVS Glycoprotein gene into a yeast integrative vector

For analysing the expression of the cloned CVS glycoprotein gene, yeast integrative vector pPICZ $\alpha A$ was used. The amplified CVS glycoprotein gene using gene specific primer having enzyme sites from cDNA were digested with EcoR I and XbaI restriction 
enzyme to create cohesive ends. Accordingly expression vector $\mathrm{pPICZ} \alpha \mathrm{A}$ was also digested with the same restriction enzymes to have compatible cohesive ends. The ligation reaction was carried out with an optimal molar ratio of 1:3 vector : insert. The components of the ligation mixture was mixed into a $0.5 \mathrm{~mL}$ microcentrifuge tube and incubated at $16^{\circ} \mathrm{C}$ for $16 \mathrm{~h}$. The competent cells of $E$. Recombinant clones were identified and the plasmid was isolated and confirmed as described earlier using gene specific PCR. Further confirmation was done by complete restriction of clones using EcoR I and XbaI restriction enzymes.

Transformation of yeast cells (Pichia pastoris, X-33) with recombinant plasmid DNA

YPD broth $(5 \mathrm{~mL})$ in a $50 \mathrm{~mL}$ conical flask was inoculated with single colony from the YPD agar plates and incubated at $30^{\circ} \mathrm{C}$ for $16 \mathrm{~h}$. With shaking (250-280 rpm). This over night culture $(0.5 \mathrm{~mL})$ was used for inoculating $500 \mathrm{~mL}$ fresh YPD broth in a $2 \mathrm{~L}$ flask and allowed to grow at $30^{\circ} \mathrm{C}$ to reach an OD600 of 1.3-1.5 (overnight incubation). The cells were pelletted at $4000 \mathrm{x} \mathrm{g}$ for $5 \mathrm{~min}$ at $4^{\circ} \mathrm{C}$ and suspended in $500 \mathrm{~mL}$ ice-cold sterile distilled water. The cells were pelletted at $4{ }^{\circ} \mathrm{C}$ as above and suspended in $250 \mathrm{~mL}$ sterile ice-cold distilled water. The cells were again pelletted at $4{ }^{\circ} \mathrm{C}$ as above and suspended in $20 \mathrm{~mL}$ sterile ice cold $1 \mathrm{M}$ sorbitol. The cells were again pelleted as above and resuspended finally in sterile ice-cold $1 \mathrm{M}$ sorbitol to a final volume of $1.5 \mathrm{~mL}$ and aliquoted as $80 \mu \mathrm{l}$ in sterile $1.5 \mathrm{~mL}$ micro centrifuge tubes and used for transferring the sacI digested recombinant pPICZ $\alpha \mathrm{A}$ having the glycoprotein gene by electroporation. 100-200 $\mu 1$ of the electroporated cells were plated on YPDS agar plates having $400-1000 \mu \mathrm{g} / \mathrm{mL}$ concentrated Zeocin and incubated at $30^{\circ} \mathrm{C}$ until the colonies appeared on the plates. Each transformants colony was grown in $10 \mathrm{~mL}$ of YPDS broth at $30^{\circ} \mathrm{C}$ till the A600 of the culture reached 0.6-1.0 (16-18h.s). The genomic DNA was isolated from yeast transformants by HiPurA kit and confirmed by PCR using specific PCR.

\section{Induction of protein expression in recombinant Pichia clones and characterization}

Induction of protein expression was done by standard procedure (Cregg et al., 1993) with modification. Buffered Glycerol- complex Medium (BMGY), in $250 \mathrm{~mL}$ flasks was inoculated with single PCR positive clone of each serotype and with insert using vector transformant of Pichia as a control. The flasks were incubated at $28-30^{\circ} \mathrm{C}$ in a shaking incubator (250-300rpm) to reach an A600 of 2-6 ( 16-18 h). The cells were harvested by centrifuging at $4000 \mathrm{xg}$ for $5 \mathrm{~min}$ at room temperature and suspended in Buffered Methanol-complex Medium (BMMY) to get an A600 of 1.0 (about $200 \mathrm{~mL}$ medium) in 1L flask to induce expression. The flasks were incubated at $30^{\circ} \mathrm{C}$ to continue the growth and methanol was added to a final concentration of 0.5 per cent at every $24 \mathrm{~h}$. to sustain the induction. Aliquots of $1 \mathrm{~mL}$ each were collected in $1.5 \mathrm{~mL}$ Eppendorf tubes at various time points i.e., $0,12,24,36,48$ 60, 72, 84, 96,108 and 120 hours and centrifuged at $15000 \mathrm{xg}$ in a table top microfuge for $5 \mathrm{~min}$ at room temperature. The supernatants containing expressed proteins were collected and the polyhistidine-containing recombinant protein was purified from the secreted media by Affinity column using His tag from the fusion protein.

Proteins expressed by Pichia clones carrying rabies virus glycoprotein genes were detected by, RT-PCR, qPCR, Sodium Dodecyl Sulfate - Poly Acrylamide Gel Electrophoresis (SDSPAGE) using discontinuous buffer system as 
followed in Western blot, ELISA as per standard procedures (Sambrook et al, 1989;). Clone without insert was used as a negative control.

Multimeriztion of cvs glycoprotein gene in Pichia pastoris (GS115) by sub-cloning into a pPIC9k vector

The amplified Glycoprotein gene from Recombinant pTZ57R/T having Glycoprotein gene were cut with EcoRI and NotI restriction enzymes. Accordingly expression vector pPIC9K was also digested with the same restriction enzymes to have compatible cohesive ends. Ligation was done by fallowing standard protocol and transformation of ligated product into $\mathrm{DH} 5 \alpha$ competent cells by using earlier mentioned protocol. Recombinant clones were identified and the plasmid was isolated and confirmed by using gene specific PCR. Further confirmation was done by complete restriction of clones using EcoR I and NotI restriction enzymes.

Transformation of yeast cells (Pichia pastoris, GS115) with recombinant plasmid DNA

The yeast cells, Pichia pastoris, GS115 were transformed with linearized plasmid with or without insert as per the standard protocols (Hennen et al., 1978; Cregg, et al., 1985). The recombinant plasmid DNA (pPIC9K- rabies virus glycoprotein gene) isolated from $25 \mathrm{~mL}$ over night culture and the linearized plasmid DNAs were used for transformation. In order to get Geneticin resistant cells, the recombinant plasmid DNAs $(\sim 20 \mu \mathrm{g})$ in $100 \mu \mathrm{l}$ was digested with Sac I enzyme. After digestion at $37^{\circ} \mathrm{C}$ for $6 \mathrm{~h}$., the linearized DNA was purified by Fermentas EeneJET PCR Purification kit. pPIC9K DNA, $80 \mu \mathrm{l}(\sim 20 \mu \mathrm{g})$ linearized with Sac I enzyme was used as control.
Transformation by electroporation and in vivo screening of multiple inserts

Freshly prepared competent cells $(80 \mu \mathrm{l})$ were mixed with $\sim 12 \mu \mathrm{g}$ of linearized plasmid, transferred to an ice-cold electroporation cuvette $(0.2 \mathrm{~cm})$ the cells were incubated for 5 min. on ice and subjected to electric field as described by the manufacturer of the electroporator, Gene Pulser. The charging voltage was $1500 \mathrm{~V}$ with a capacitance of $25 \mu \mathrm{F}$ at 2000 resistance which gives field strength of $\sim 7500 \mathrm{~V}$ fern. Immediately after giving the electric pulse (within 8 seconds), $1 \mathrm{~mL}$ of icecold $1 \mathrm{M}$ sorbitol was added to the cuvette and the contents were transferred to a sterile microfuge tube. From this about $100-200 \mu 1$ of the cells were plated on YPDS agar plates having $\quad 0.25 \mathrm{mg}-4 \mathrm{mg} / \mathrm{mL} \quad$ concentrated Geneticin and incubated at $30^{\circ} \mathrm{C}$ until the colonies appeared on the plates.

1.Pipetted 1 to $2 \mathrm{~mL}$ sterile water over the $0.25 \mathrm{mg} / \mathrm{mL}$ Geneticin resistant transformants on each plate.

2. Resuspened the $0.25 \mathrm{mg} / \mathrm{mL}$ Geneticin resistant transformants into the water by using a sterile spreader and running it across the top of the agar.

3.Transferred the cell suspension into a sterile, $50 \mathrm{~mL}$ conical centrifuge tube and vortex briefly ( 5 to $10 \mathrm{sec}$ ).

4. Determined cell density using a spectrophotometer and Plated $10^{5}$ cells on YPD plates containing Geneticin ${ }^{\circledR}$ at a final concentration of $0.25,0.5,0.75,1.0,1.5,1.75$, $2.0,3.0$, and $4.0 \mathrm{mg} / \mathrm{mL}$.

5. Incubated the plates at $30^{\circ} \mathrm{C}$ and checked daily. Geneticin-resistant colonies were taken 2 to 5 days to appear while cells plated on YPD will take 2-3 days. 
There were only a few Geneticin resistant colonies, and they may be of different sizes, but the colony morphology was same. Picked all Geneticin resistant colonies and purified by streaking for single colonies. Glycoprotein gene insertion was analyzed by PCR by isolating the genomic

DNA, and done the Real time PCR for colonies grown on higher concentration of Geneticin to know the copy number by comparing with $0.25 \mathrm{mg} / \mathrm{mL}$ Geneticin resistant colonies. The cybergreen from Biorad was used for Real time PCR and procedure fallowed as for the instruction of the company manual.

\section{Results and Discussion}

PCR amplification of CVS rabies glycoprotein gene from cDNA and sequencing

Total RNA was isolated from BHK-21 cell line infected with CVS rabies virus and constructed the gene specific cDNA Using glycoprotein forward primer. Rabies Glycoprotein gene was amplified from gene specific cDNA using Glycoprotein specific primers designed using reported Rabies nucleotide sequence from the database. The amplicons so obtained were separated on 1.0 per cent agarose gel is presented in Plate 1. From the gel, it is clear that an amplicon of 1575 bp was obtained from amplification of Rabies Glycoprotein gene. This amplicon was cloned into cloning vector $\mathrm{pTZ57R/T}$. The recombinant molecules were transferred into E. coli $\mathrm{DH} 5 \alpha$ using $5 \mu \mathrm{l}$ of ligation mixture. The transformed cells were picked up and streaked on Luria agar containing amplicillin $(100 \mathrm{mg} / \mathrm{mL})$, X-gal and isopropyl -Dthiogalactosidase (IPTG). The clones containing recombinant molecules were selected based on blue-white colonies. Plasmids were isolated from white colonies contained Rabies Glycoprotein gene and the clones were confirmed through PCR amplification by using specific primers (Plate $2)$. The confirmed recombinant vectors with Rabies Glycoprotein were named pNRCRG1506.

The construct pNRCRG1506 was sequenced completely using M13 primers and by employing primer walking technique. Figure 1 represent the map of pNRCRG1506, the complete sequence of nucleotide and amino acid sequences of Rabies Glycoprotein gene is presented in Figure 2 and 4. Sequenced Glycoprotein gene was analyzed for the presence frequently used restriction sites and represent in Figure 3.

Cloning of rabies glycoprotein gene into yeast Integrative vector and transformation into Pichia pastoris (X-33)

The Glycoprotein gene was amplified from pNRCRG1506 using Glycoprotein specific forward and reverse primers having EcoRI and $X b a I$ sites respectively to clone into pPICZ $\alpha \mathrm{A}$ directionally by restricting the vector with same enzyme with that of the gene. The pPICZ $\alpha A$ containing Glycoprotein was transformed into DH5 $\alpha$ and confirmed by PCR with pPICZ $\alpha$ A vector DNA as negative control. The recombinant plasmid DNA gave amplicon of $1575 \mathrm{bp}$, and named this construct as pNRCRG1510 (Fig. 5, 6 \& 7) while in pPICZ $\alpha A$ vector; there was no amplification (Plate 3). The positive clones were also confirmed by restriction digestion with EcoRI and XbaI (Plate 4).

The recombinant clone pNRCRG1510 was linearized with SacI enzyme to express the full length of Glycoprotein in Pichia pastoris and confirmed by running on one per cent gel (plate 5). The linearized pNRCRG1510 was transferred to elecrocompetent Pichia pastoris by electroporation as described in the material 
and methods. Similarly pPIZ $\alpha A$ vector was transferred into Pichia and transferred Pichia pastoris was plated on YPD having 400$1000 \mu \mathrm{g}$ of Zeocin. The antibiotic resistant Pichia colonies were screened for the selection of recombinant Pichia for Glycoprotein gene by PCR using Glycoprotein gene specific primers. A single and intense DNA band of size 1575 bp could be seen in case of positive colonies carrying full length glycoprotein gene, which grew on zeocin, indicating the presence of glycoprotein gene insert (Plate.6) in yeast genome.

\section{Analysis of pichia Expressed glycoprotein} by RT-PCR and SDS-PAGE

Positive and control Pichia clones were induced using 0.5per cent methanol for $96 \mathrm{~h}$. and pelleted the cells. The total RNA isolated from both glycoprotein positive Pichia clone and controls were quantified using a Biophotometer at $260 \mathrm{~nm}$. Equal amount of RNA was used for construction of cDNA using Reverse Transcriptase subjected to PCR by using specific primers for Glycoprotein gene. The amplicon of $1575 \mathrm{bp}$ was observed in recombinant Pichia and it was absent in control (plate 7).

The culture supernatant from shake flask culture of induced Glycoprotein was purified by anti nickel column. The purified protein was analyzed by SDS-PAGE and quantified by Bradford reagent as $100 \mathrm{mg} / \mathrm{mL}$. After destaining, the gel was examined under X-ray illumination and documented (Plate. 8). There was a single protein band, which could be seen in the gel. Upon comparison of protein profile of the recombinant clones (lane 2 and 3 ) with protein ladder, the protein position is around $78 \mathrm{kDa}$. Since the full length glycoprotein gene insert is $1575 \mathrm{bp}$ and signal sequence along with histag the expected size of the protein expressed, should be around 76$78 \mathrm{kDa}$. Therefore, the band at position 78
$\mathrm{kDa}$ may correspond to the cloned gene product. Cells free extract from positive culture supernatant of induced glycoprotein was concentrated by passing through $30 \mathrm{kd}$ cut-off centrican column and quantified by Bradford reagent. Rabies Glycoprotein was also precipitated from cells free extract of positive clones by Ammonium sulphate and quantified by Bradford reagent along with standards.

\section{ELISA and Western blotting assay for the expressed protein}

The Glycoprotein of CVS rabies virus produced in Pichia pastoris was further analyzed by western blot analysis using sera raised against whole virus (Plate.9). The commercial human vaccine was used as a positive control.

The blot showed positive colour reactions with the proteins of both the clones (lane, 2)) and in Commercial vaccine (lane, 1). However the differences in size of the protein between commercial vaccine and purified recombinant Glycoprotein can be attributed to the His tag and $\alpha$ secretary signal form the yeast integrative vector. While in ammonium precipitated protein, the tag and secretory signal might have been removed during precipitation. The CVS rabies virus Glycoprotein was further confirmed by ELSA.

Western blot positive Pichia expressed glycoprotein was further confirmed by coating the $1 \mu \mathrm{g}$ of antigen and antiserum with different dilutions were used as primary antibody as for the protocol described in the material and methods.

At Dilution of 1:500 in clone 8 got maximum OD of 1.533 as compare to clone7 of OD 0.956 and at 1:1000 dilution in clone 8 got OD of 1.008 where as in clone 7 got the OD of 0.512 (Table 1 and Fig. 8). 
Multimerization of Glycoprotein gene cassette in Pichia pastoris (GS115) by cloning into PPIC9K vector

The Glycoprotein gene was amplified from pNRCRG1506 using Glycoprotein specific primers having sites of EcoRI and NotI sites in forward and reverse primer respectively to clone into pPIC9K directionally by restricting the vector with same enzyme with that of gene. The vector and insert from pNRCRG1506 was ligated at 1:3 molar ratio, were used. The transformants in E. coli $\mathrm{DH} 5 \alpha$ were picked and streaked on Luria agar plates containing $100 \mu \mathrm{g} / \mathrm{mL}$ Ampicilin. The pPIC9K containing Glycoprotein was confirmed by PCR with pPIC9K vector DNA as negative control. The recombinant plasmid DNA gave amplicon of $1575 \mathrm{bp}$, and named this construct as pNRCRG2504 (Fig. 9) while in pPIC9k vector; there was no amplification (Plate10). These clones were also confirmed by restriction digestion with EcoRI and NotI (Plate 11).

The recombinant pNRCRG2504 vector was linearized with SacI enzyme to integrate multicopy Glycoprotein cassette and express the full length of Glycoprotein in Pichia pastoris (GS115).

The linearized pNRCRG2504 was transferred to elecrocompetent Pichia pastoris (GS115) by electroporation as described in the material and methods. Similarly pPIC9K vector was transferred into Pichia pastoris (GS115) and Transferred Pichia pastoris was plated on YPD having $0.25 \mathrm{mg} / \mathrm{mL}$ of Genetcin.

\section{Screening of recombinant Pichia (GS115) clones for multicopy inserts}

Multicopy Glycoprotein cassette inserted Pichia clones were screened by plating the Pichia transforments on $0.25 \mathrm{mg} / \mathrm{mL}$ Geneticin plates. $0.25 \mathrm{mg} / \mathrm{mL}$ Geneticin resistant Pichia colonies were replated on higher concentrated Geneticin $(2 \mathrm{mg}$ and $4 \mathrm{mg} / \mathrm{mL})$ for the selection of recombinant Pichia for Multicopy Glycoprotein gene. Genomic DNAs was isolated from Geneticin resistant colonies transformed by recombinant DNAs and a vector transformant colony were extracted separately as described under material and methods and subjected to PCR amplification with gene specific primers for the presence of the insert. The amplified products were analyzed by agarose gel electrophoresis using standard molecular weight markers (Plate.12). A Single and intense DNA band of size $1575 \mathrm{bp}$ could be seen in case of positive colonies carrying full length glycoprotein gene, which grew on Geneticin, indicating the presence of glycoprotein gene insert in yeast genome. While there was no amplification in Pichia pastoris transferred with vector without insert.

Real time PCR was carried out using template DNA isolated from $0.25,2$ and $4 \mathrm{mg} / \mathrm{mL}$ Geneticin resistant colonies. Pichia colony resistant to $4 \mathrm{mg} / \mathrm{mL}$ Geneticin was crossed the threshold level at $21^{\text {st }}$ cycle, $2 \mathrm{mg} / \mathrm{mL}$ Geneticin resistant colony was crossed at $22^{\text {st }}$ cycle and $0.25 \mathrm{mg} / \mathrm{mL}$ Geneticin resistant colony was crossed at $24^{\text {th }}$ cycle, indicating the $4 \mathrm{mg} / \mathrm{mL}$ Geneticin resistant colony has got more copy of Glycoprotein insert followed by $2 \mathrm{mg} / \mathrm{mL}$ Geneticin resistant colony and then with $0.25 \mathrm{mg} / \mathrm{mL}$ Geneticin resistant colony (Fig. 10). Rabies is currently an incurable disease with a mortality rate of 100per cent, if not immediately treated after the first debilitating nervous symptoms, making it one of the most dangerous zoonotic viral diseases to both humans and animals (NASPHV, 2007; Sudarshan et al., 2007; Zhang et al., 2005; Knobel et al., 2005; Schneider et al., 2007) Yet, efficient diagnostic and safe treatment remains unaffordable in regions where it is most endemic. 
Table1. ELISA absorbance values recorded at $450 \mathrm{~nm}$ for CVS Rabies Glycoprotein extracted from Pichia positive clone of seven and eight.

\begin{tabular}{|c|c|c|}
\hline $\begin{array}{c}\text { Serum at } \\
\text { different dilution }\end{array}$ & $\begin{array}{c}\text { Glycoprotein from } \\
\text { cell free extract of } \\
\text { Pichia Clone eight }\end{array}$ & $\begin{array}{c}\text { Glycoprotein from cell } \\
\text { free extract of Pichia } \\
\text { Clone seven }\end{array}$ \\
OD
\end{tabular}

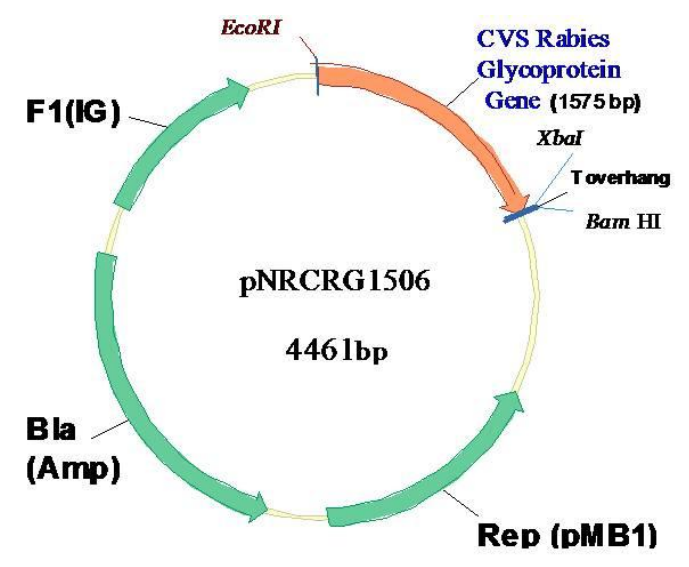

Fig 1. Construet map of pNRCRG1506 containing full length CVS Rabies Glycoprotein gene in pTZ57R/T 


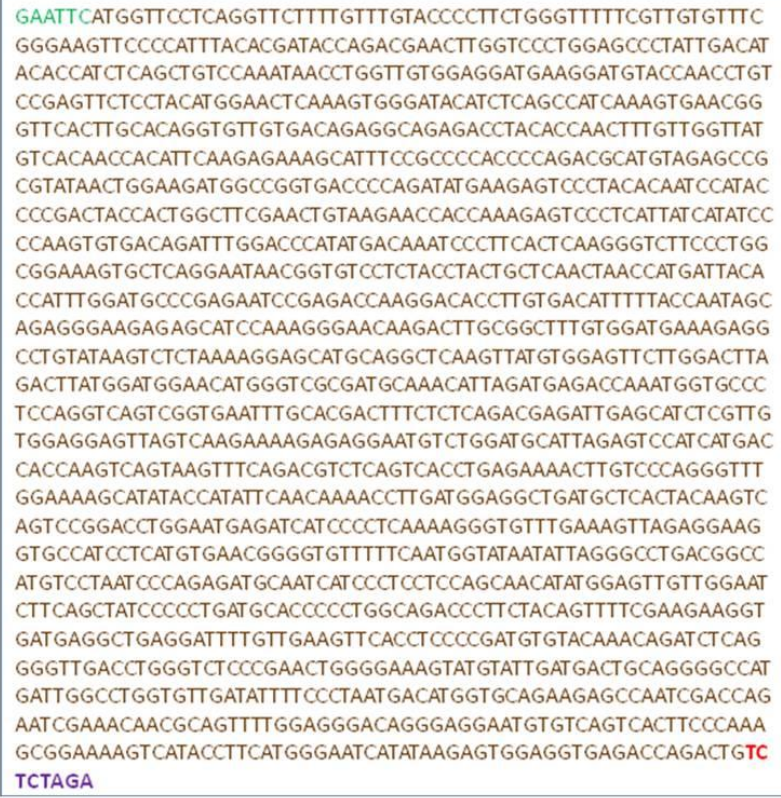

Fig 2.Complete sequence of cloned CVS Rabies Glycoprotein gene along with added base pairs and restriction sites

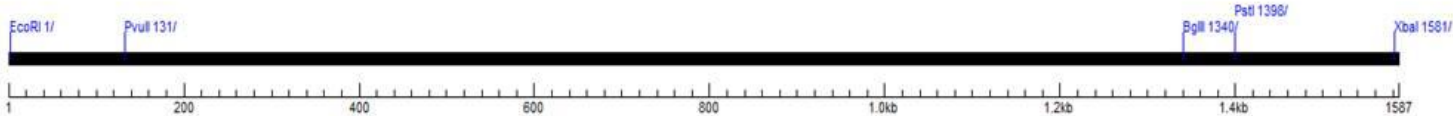

Fig 3. Restriction sits present in Sequenced CVS Rabies Glycoprotein gene

\begin{abstract}
MVPQVLLFVPLLGFSLCFGKFPIYTIPDELGPWSPIDIHHLSCPNNLVVEDE GCTNLSEFSYMELKVGYISAIKVNGFTCTGVVTEAETYTNFVGYVTTTFK RKHFRPTPDACRAAYNWKMAGDPRYEESLHNPYPDYHWLRTVRTTKES LIIISPSVTDLDPYDKSLHSRVFPGGKCSGITVSSTYCSTNHDYTIWMPENP RPRTPCDIFTNSRGKRASKGNKTCGFVDERGLYKSLKGACRLKLCGVLG LRLMDGTWVAMQTLDETKWCPPGQSVNLHDFLSDEIEHLVVEELVKKR EECLDALESIMTTKSVSFRRLSHLRKLVPGFGKAYTIFNKTLMEADAHYK SVRTWNEIIPSKGCLKVRGRCHPHVNGVFFNGIILGPDGHVLIPEMQSSLL QQHMELLESSAIPLMHPLADPSTVFEEGDEAEDFVEVHLPDVYKQISGVD LGLPNWGKYVLMTAGAMIGLVLIFSLMTWCRRANRPESKQRSFGGTGR NVSVTSQSGKVIPSWESYKSGGETRL
\end{abstract}

Fig 4.Amino acids sequence of cloned Rabies Glycoprotein gene 


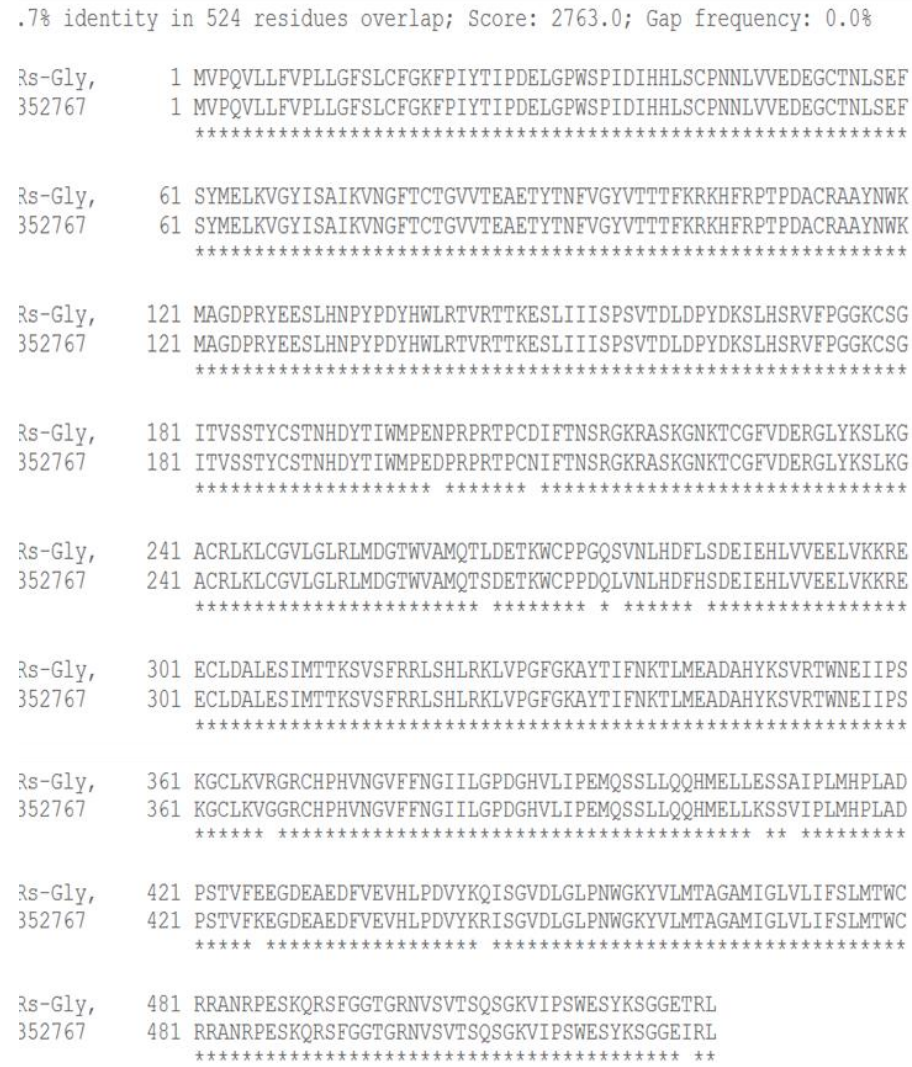

\section{Fig 6. Conserved protein domain of cloned Rabies Glycoprotein}

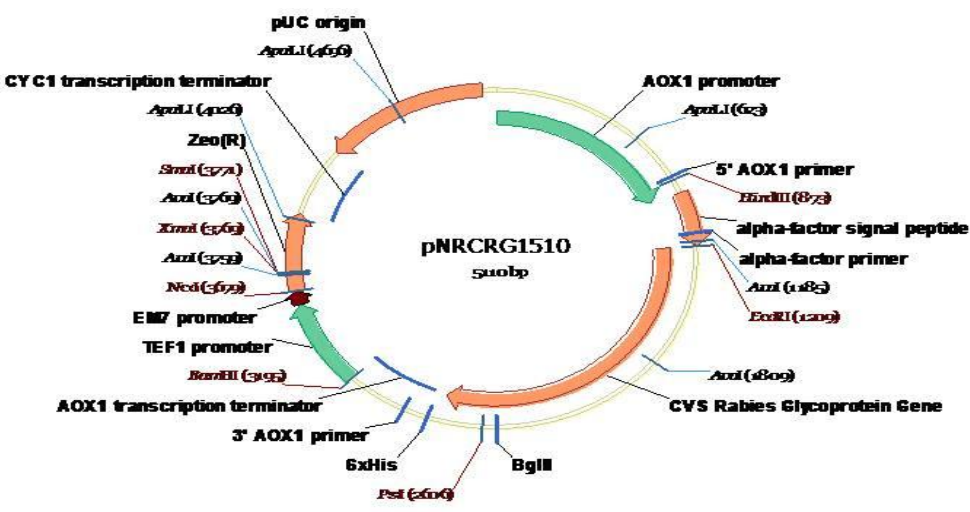

Fig 7.Construet map of pNRCRG1510 containing full length gene of Rabies Glycoprotein gene 


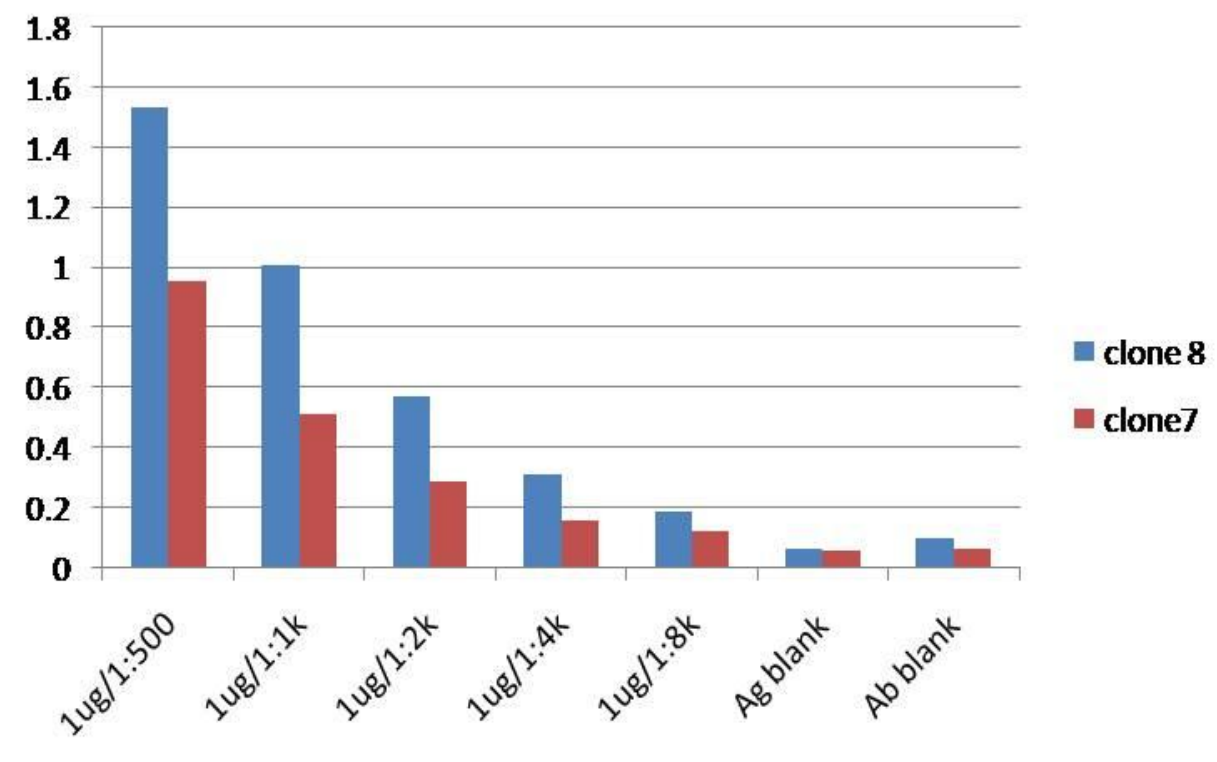

Fig 8. ELISA of Rabies Glycoprotein using anti sera

$\mathrm{X}$ axis $-\mathrm{OD}$

Y axis - Serum at different dilution

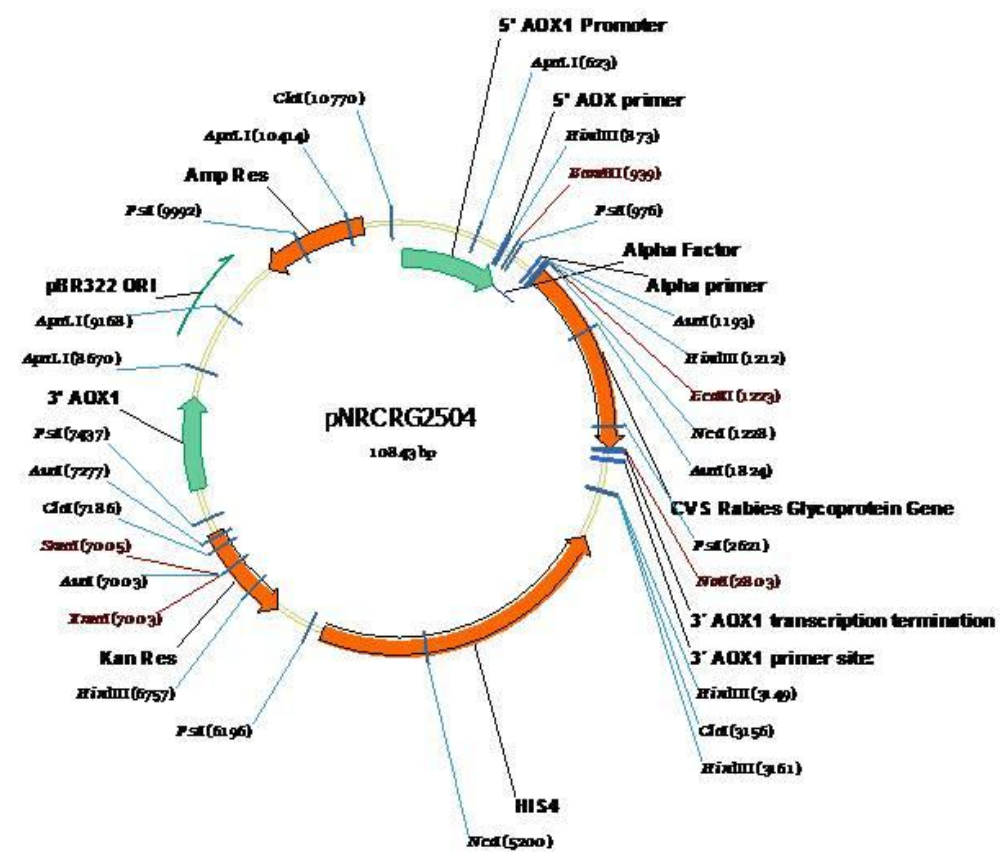

Fig.9 .Construct map of pNRCRG2504 containing full length gene of Rabies Glycoprotein gene 


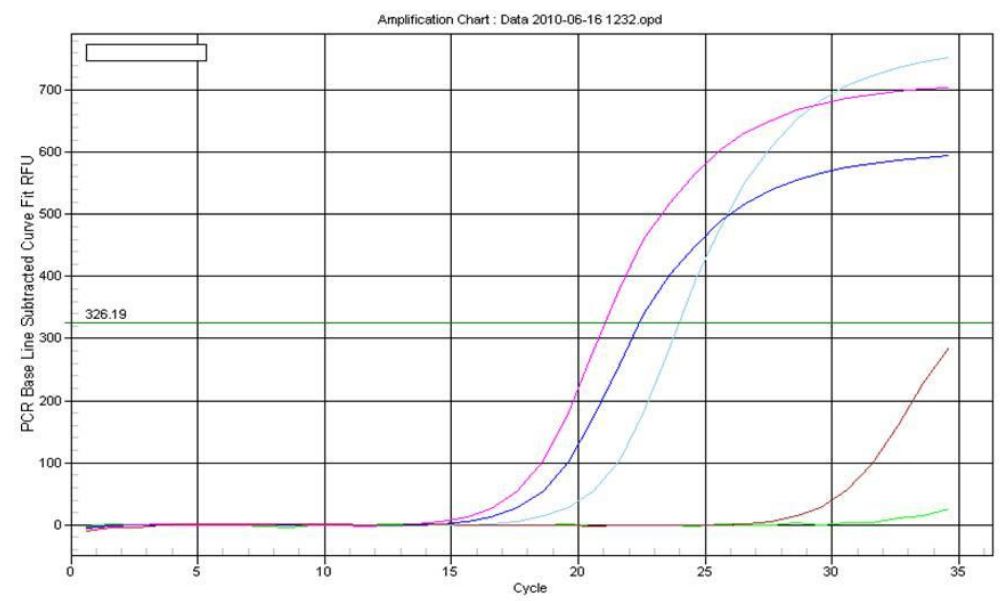

Fig 10. Real time PCR Analysis of Pichia pastoris clones containing Rabies Glycoprotein resistant to Geneticin Pink- Pichia (GS115) colony resistant to $4 \mathrm{mg} / \mathrm{ml}$ Geneticin. Blue- Pichia (GS115) colony resistant to $2 \mathrm{mg} / \mathrm{ml} \mathrm{Geneticin}$ Light green- Pichia (GS115) colony resistant to $0.25 \mathrm{mg} / \mathrm{ml}$ Geneticin Red - Pichia (GS115) host with vector

Green - water control

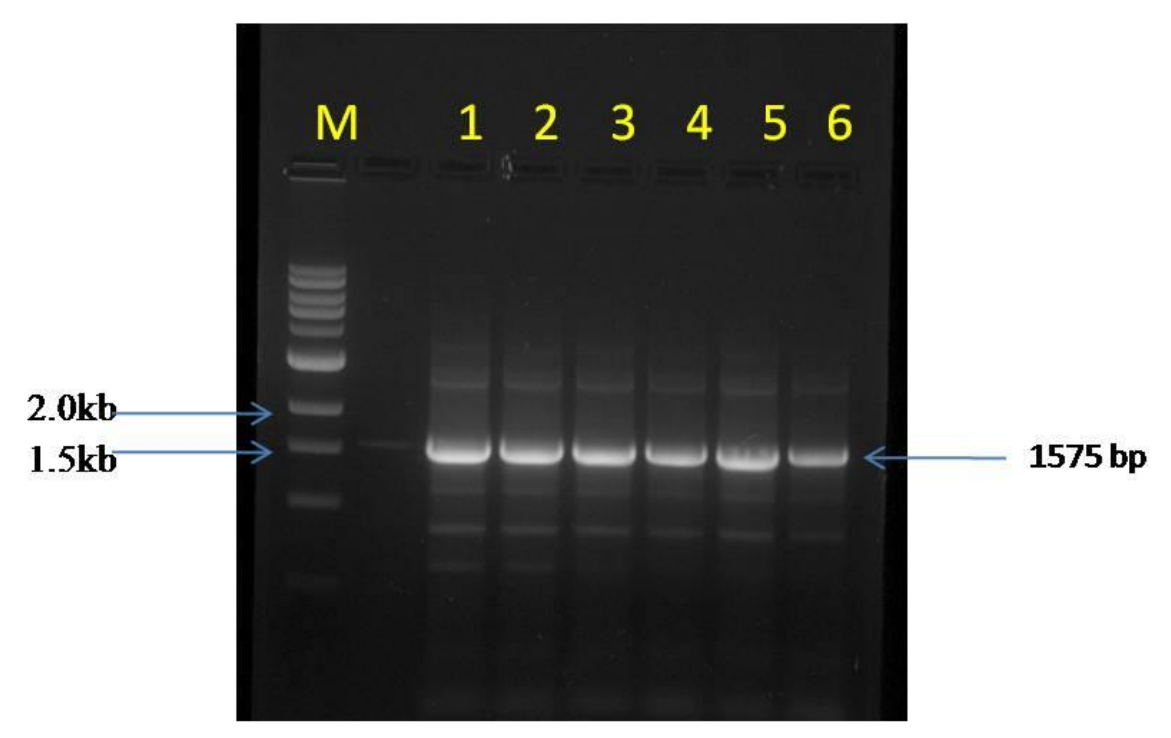

Plate. 1 PCR amplification of Rabies Glycoprotein gene from eDNA M- $1 \mathrm{~Kb}$ ladder

Lane 1,2,3,4,5 and 6-Amplification Glycoprotein with different concentration of cDNA 


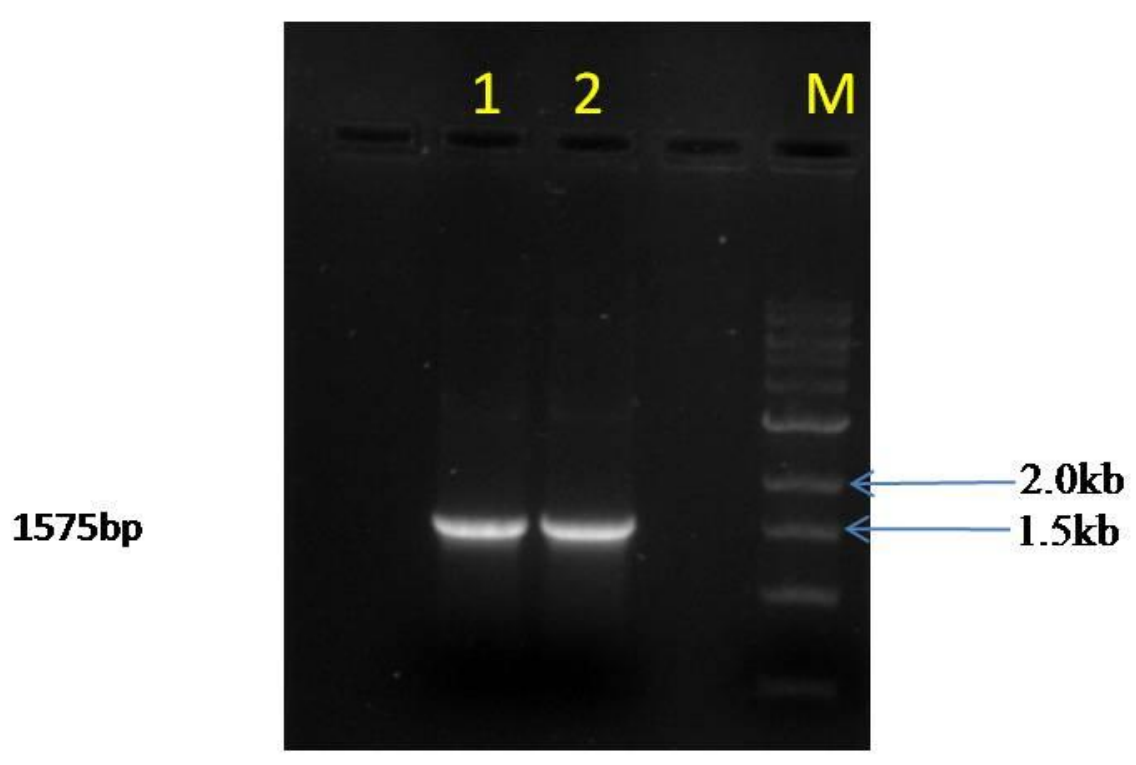

Plate .2 PCR confirmation of Construct pNRCRG1506

Lane M - 1 Kb ladder

Lane 1 and 2 - clones

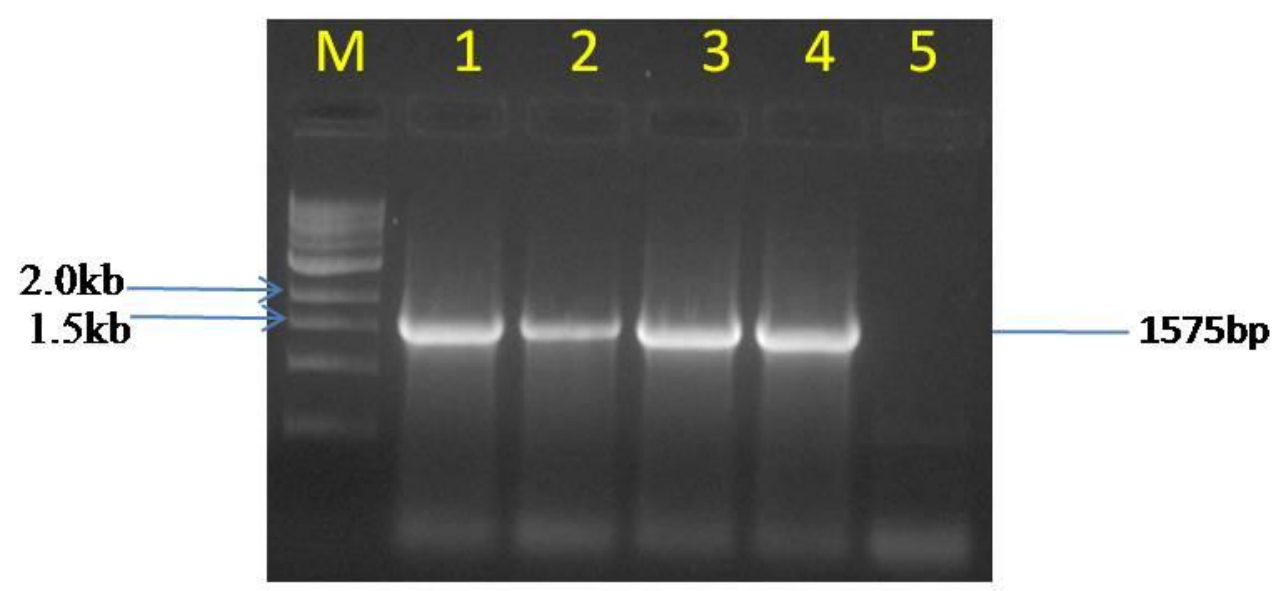

Plate 3. PCR confirmation of Construct PNRCRG1510

M- 1 kb ladder

Lane 1,2,3 and 4 -clones

Lane 5- Negative control(vector) 

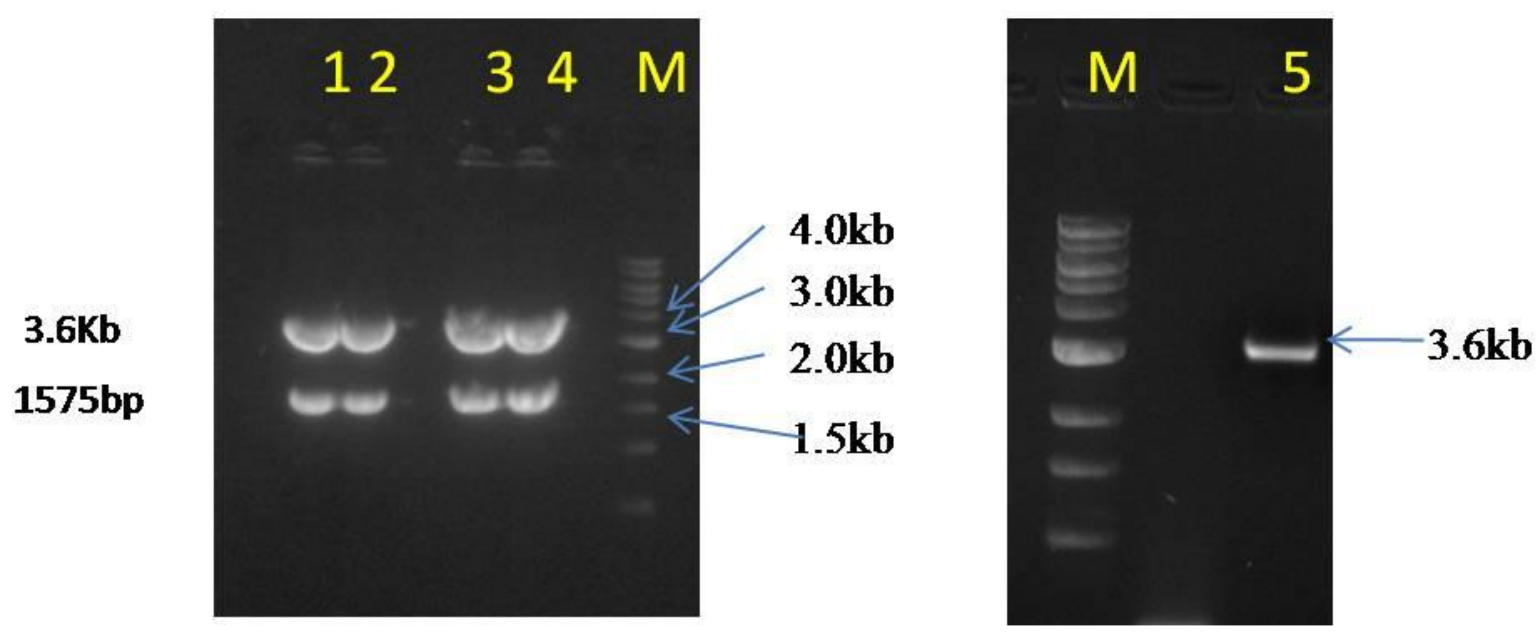

Plate 4. Restriction digestion of Construet pNRCRG1510

M- 1 kb ladder

Lane 1,2,3 and 4 - clones

Lane 5 - vector

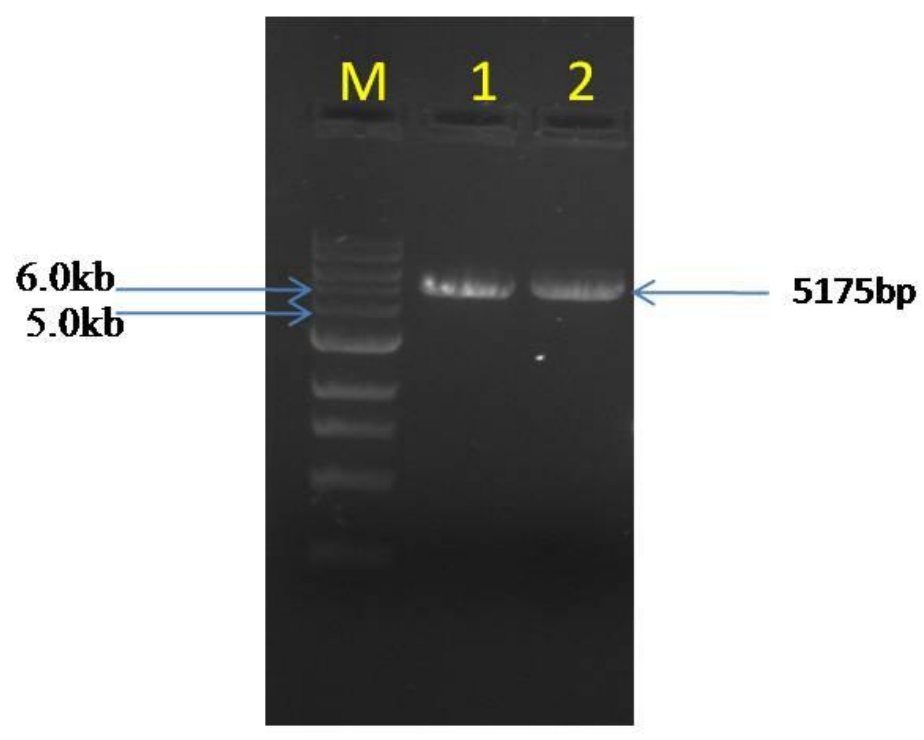

Plate 5. linearization of Construct

PNRCRG1510

$\mathrm{M}-1 \mathrm{~Kb}$ ladder,

1 and 2 -clones 


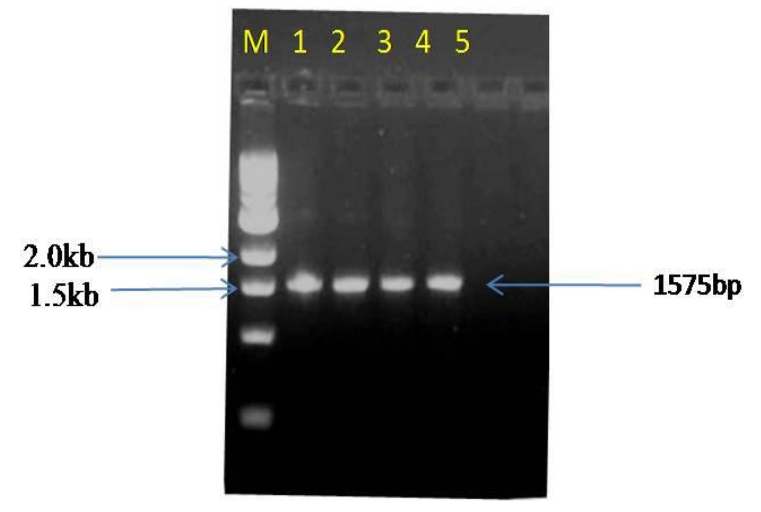

Plate 6. PCR confirmation of Pichia clones for Rabies Glycoprotein 1- positive control(pNRCRG1510)

2,3 and 4-Pichia clones 5- Negative control

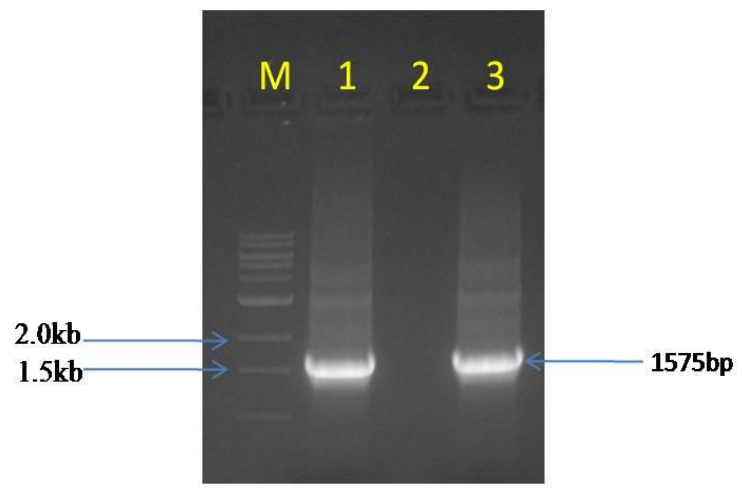

Plate 7. RT-PCR of Rabies Glycoprotein gene

$\mathrm{M}$ - $1 \mathrm{~Kb}$ ladder

Lanel and3-clones

Lane 2- host with vector

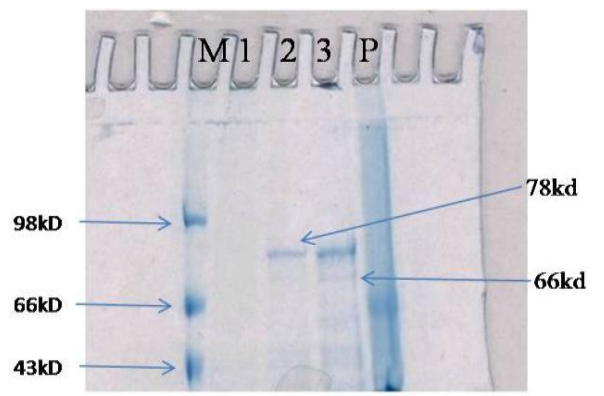

Plate 8. SDS PAGE analysis of purified Rabies Glycoprotein produced im Pichia pastoris

M- protein marker

lanel-Pichia host with vector

Lane 2 and 3 - protein from Pichia clones

P- commercial vaccine 


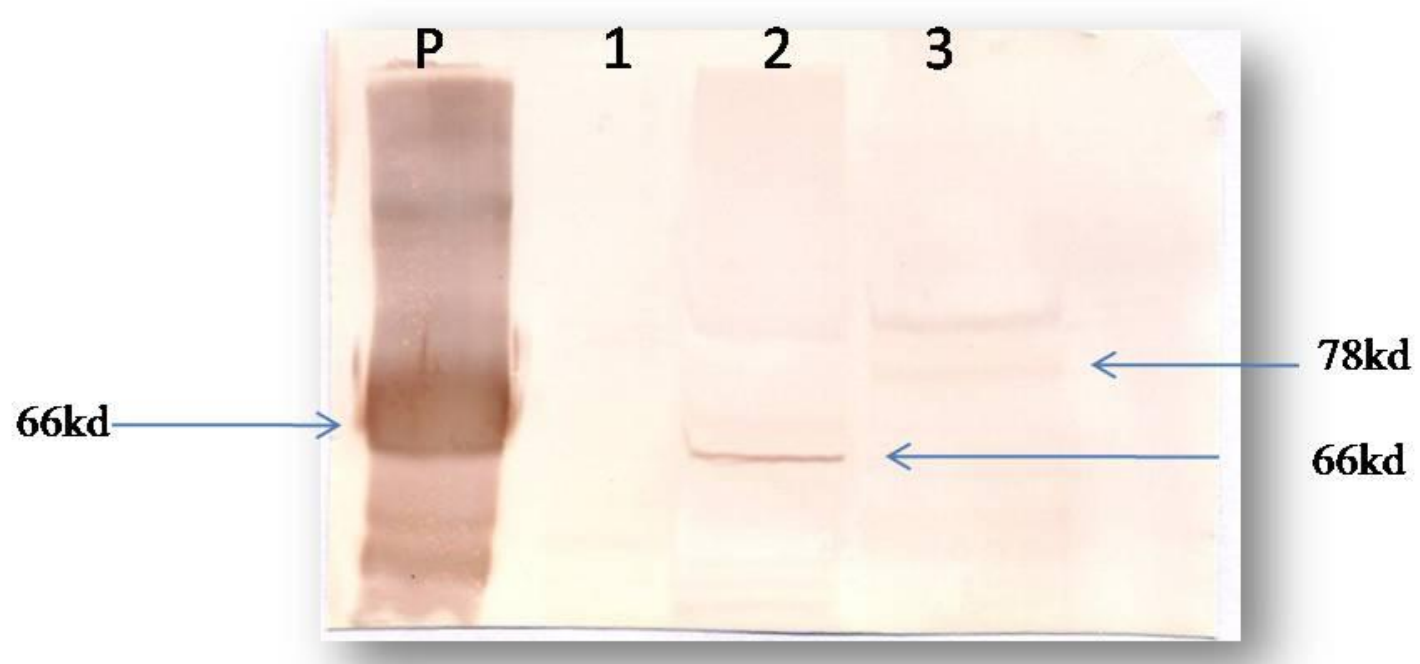

Plate 9. Western blot analysis of purified Rabies Glycoprotein produced in Pichia pastoris

Lane P-commercial vaccine

Lane 2-Ammonium sulphate precipitated Rabies Glycoprotein from Pichia clones

Lane3- His tag purified Glycoprotein from Pichia clones

Lane 1 - Pichia pastoris host protein.

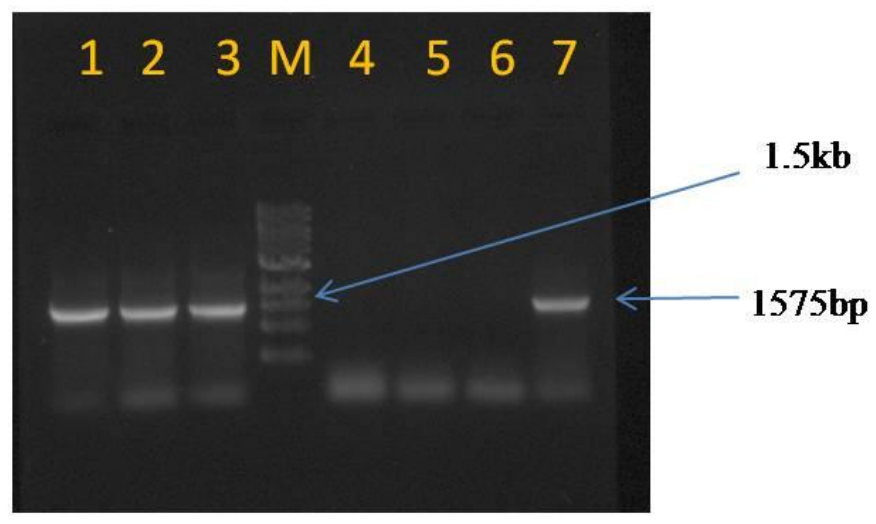

Plate 10. PCR confirmation of Construct PNRCRG2504

Lane 2,3, and 7- clones

Lane 1- positive control

Lane 4,5 and 6- Negative control 


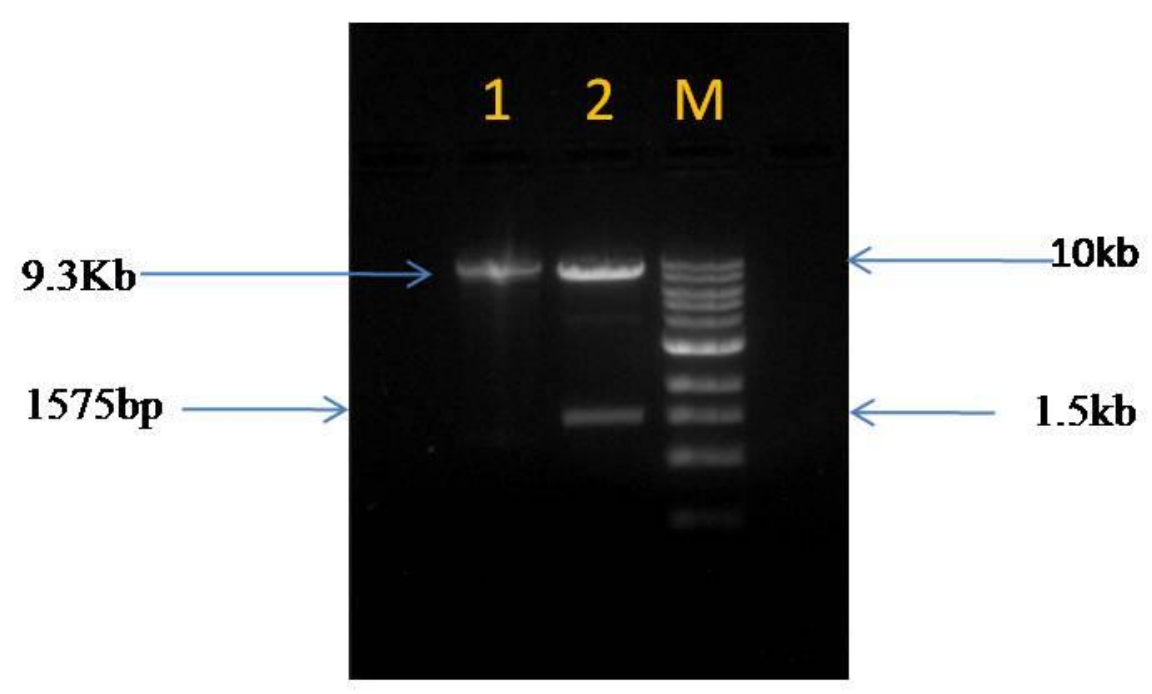

Plate 11. Restriction analysis of Construct PNRCRG2504

Lane 1- digested vector

Lane 2 -digested pNRCRG2504

$\mathrm{M}-1 \mathrm{~Kb}$ ladder

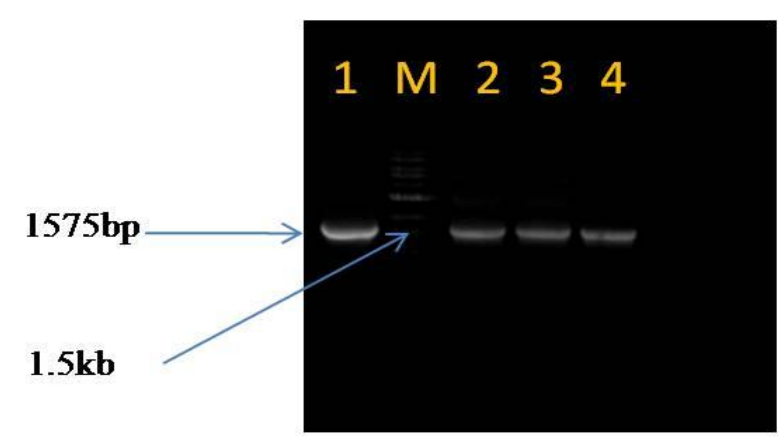

Plate 12. PCR Confirmation of Rabies Glycoprotein gene integration in Pichia pastoris(GS115) clones.

Lane1 - construct pNRCRG2504

M-1Kh ladder

2,3and 4 -clones

The presently available vaccines for rabies include neural tissue derived (NTO), simple vaccine and cell culture derived vaccine. The NTO vaccine is still administered to a large number of people in developing countries, though it causes a lot of serious side effects.
Cell culture vaccines are expensive for routine use in developing countries.

Recombinant gene expression is among the most important techniques used both in molecular and medical research and in 
industrial settings. Over the last few decades, the Pichia pastoris expression system has been used successfully for production of various recombinant heterologous proteins. The use of the methylotrophic yeast, Pichia pastoris, as a cellular host for the expression of recombinant proteins has become increasingly popular in recent times. $P$. pastoris is easier to genetically manipulate and culture than mammalian cells and can be grown to high cell densities. Equally important, $P$. pastoris is also a eukaryote, and thereby provides the potential for producing soluble, correctly folded recombinant proteins that have undergone all the post-translational modifications required for functionality. A further benefit of the $P$. pastoris system is that strong promoters are available to drive the expression of a foreign gene(s) of interest, thus enabling production of large amounts of the target protein(s) with relative technical ease and at a lower cost than most other eukaryotic systems (Daly and Hearn, 2005). This presumption and other success reports on yeast expressed recombinant Polio (Rombaut and Jore, 1997), Bovine herpes virus-1 (Zhu, et al., 1997), Dengue virus (Sugrue et al., 1997) and Hepatitis B Virus Surface Antigen (Liu et al., 2009) vaccines have prompted us to evaluate Pichia pastoris as a host to express the Glycoprotein of CVS rabies virus, for using as animal vaccines.

Therefore, the present study was undertaken to clone, express and overexpress the glycoprotein gene coding for transmembrane glycoprotein of CVS rabies virus in Pichia pastoris as secretary products and the results of which are discussed here. BHK-21 cells infected with CVS rabies was obtained from the NIMHANS and total RNA was isolated from that cells. Gene specific cDNA was constructed using Forward primer, from this cDNA full length Glycoprotein gene was amplified using gene specific primers. Sakamoto et al, (1999) used the G-cDNA clone pRNSL, which was isolated from cDNA library that was prepared by reversetranscribing the mRNA extracted from the hamster HmLu cells infected with rabies virus (sub strain N-HL of the Nishigahara strain was used). The amplified Glycoprotein was cloned into TA cloning vector $\mathrm{pTZ57R/T}$ and confirmed the gene by PCR using specific primers. The Rabies Glycoprotein gene was also confirmed by sequencing using M13 primer, and named this recombinant vector as pNRCRG1506. Tomar et al., amplified the RVG gene (1590 bp) using gene specific primers, The amplified Glycoprotein gene was cloned into pTZ57R/T cloning vector by TA cloning. RVG gene was subcloned into pcDNA3.1 (+) expression vector to express rabies virus glycoprotein gene into eukaryotic system and determination of potential T-cell epitopes. The confirmed CVS rabies Glycoprotein gene was amplified from the construct pNRCRG1506 using High fidelity Taq polymerase and gene specific primer having EcoRI and XbaI site. Pichia integrative vector $\mathrm{pPICZ} \alpha \mathrm{A}$ was digested with same enzymes and cloned the digested Glycoprotein amplicon directionally. The ligated vector was transferred to $\mathrm{DH} 5 \alpha$ cells for maintaining the construct then it was confirmed by PCR and restriction digestion. The recombinant construct of $\mathrm{pPICZ} \alpha \mathrm{A}$ with Glycoprotein was named as pNRCRG1510.

The pNRCRG1510 was linearized with SacI enzyme and transferred to Pichia pastoris (X33) by electroporation then plated on YPD Zeocin plates. Genomic DNA was isolated from Zeocin resistant Pichia clones and confirmed the integration of Glycoprotein gene in Pichia genomic DNA by PCR. Su et al., 2009 constructed the recombinant human apolipoprotein E3 in pPICZaC and subjected to transformation with SacI-linearized version of pPICZaC-rhApoE3, which favoured its insertion into the Pichia (X-33) genome by homologous recombination. Daly and Hearn 
(2005) confirmed the Integration of gene of interest in Pichia pastoris and the type (insertion or replacement) of events by southern blot analysis hybridized with a probe generated from the AOX1 promoter region.

PCR positive Pichia pastoris recombinants for glycoprotein were induced by grown on methanol complex media having 0.5 per cent methanol for $96 \mathrm{hr}$ and checked for the induction of Glycoprotein transcript by isolating total RNA from 0.5 per cent methanol induced Pichia cells along with host transferred with vector. The cDNA was constructed from the isolated total RNA. The cDNA was amplified with PCR using Glycoprotein specific primers. Agarose gel electrophoresis indicated that there was an amplicon at $1575 \mathrm{bp}$ band in recombinant clones and no band was observed in control. This clearly shown that, the presence of Rabies Glycoprotein transcript in recombinant Pichia clones. The same cDNA was used as template for real time PCR and there was a differential concentration of transcript in different Glycoprotein Pichia clones. Benmaamar et al., (2009) studied the engineered RNA-based rabies virus glycoprotein (RVGP) expression vector based on the Semliki Forest Virus (SFV) system. A recombinant SFV carrying an RNA coding for RVGP (SFV-RVGP) was constructed and the RVGP expression was evaluated in animal cell cultures. The mRNA coding for RVGP and the RVGP itself were assessed by RTPCR, qPCR and western blot.

Rabies Glycoprotein purified from Cell free extracts of induced RT-PCR positive clones, by using anti nickel column. Glycoprotein was confirmed by SDS PAGE along with protein ladder, which revealed that the protein size is nearly 76-78Kd. Sakamoto et al., 1999, reported 56 to $66 \mathrm{Kd}$ Rabies Glycoprotein produced in yeast cells. The increased in molecular mass weight in our experiment might be due to alpha secretory signal and his tags which adds nearly $12 \mathrm{kd}$ protein. Salah et $a l$., 2009 reported the increased size of the Rabies Glycoprotein is due to posttranslational modification of secreted proteins such as O-glycosylation, lipidation or phosphorylation. In our experiment, the Pichia produced G protein is comparable to authentic $G$ protein since it was normally reacted with the confirmation epitope anti-G MAbs. Cells free extract containing rabies glycoprotein was concentrated by passing through 30kd cut-off centrican column and Rabies Glycoprotein was also precipitated from cells free extract of positive clones by Ammonium sulphate and quantified by Bradford reagent along with standards. The concentrated recombinant protein was used for western blotting.

The results of Western blot using a mouse polyclonal immunoglobulin-G, raised against the commercial Rabies vaccine further demonstrated that the protein isolated from cells free extract of induced positive Rabies glycoprotein Pichia clones were primarily Rabies Glycoprotein. Western blotting revealed a $66 \mathrm{kd}$ band from ammonium sulphate precipitated protein of clone eight and also in commercial vaccine. Whereas protein purified form anti nickel column has shown faint band in higher molecular weight, this may be due to Glycoprotein having alpha secretory signal and histidin tag. In Westernblotting assays, a significant level of RVGP expression was observed in BHK-21 cells infected with SFV-RVGP, at 24 and $48 \mathrm{~h}$. Expression could be monitored by using antibodies against RVGP itself or against the M2-FLAG-tag expressed in fusion with the N-terminal RVGP end. The synthesized RVGP exhibited the expected molecular mass of $80 \mathrm{kDa}$ which corresponds to the recombinant $65 \mathrm{kDa}$ RVGP protein with the additional $15 \mathrm{kDa}$ fusion tags (Benmaamar et al., 2009). Cell free extracts of rabies 
Glycoprotein positive Pichia clones were further confirmed by ELISA, by coating $1 \mu \mathrm{g}$ Ammoniun precipitated rabies glycoprotein of clone seven and eight along with anti sera of rabies commercial vaccine. Clone eight has got the OD of one at 1:1000 anti rabies serum dilution whereas clone seven has got at 1:500 dilution indicating that clone eight is efficient than seven. In a similar study Su et al., (2009) studied the full-length sequence encoding Apolipoprotein E3, gained by RT-PCR, was inserted into the $\mathrm{pPICZ} \alpha \mathrm{C}$ vector and transformed into $\mathrm{P}$. pastoris strain $\mathrm{X}-33$, and then confirmed the expressed protein by ELISA using the mouse anti-human ApoE monoclonal antibody.

In vivo multimerization strategy was followed to increase the Rabies Glycoprotein production in Pichia by cloning pPIC9K vector, where it provides a Multicopy insertion of Glycoprotein cassette into Pichia genome by homologous recombination at AOX site. Insertion of Glycoprotein in Pichia pastoris (GS115) was confirmed by PCR. Multicopy inserted colonies were selected by growing on increased concentration of YPD Geneticin plates. Geneticin resistant colonies of $0.25,2$ and $4 \mathrm{mg} / \mathrm{mL}$ were confirmed by PCR. Real time PCR was performed on these colonies to know the copy number. The Pichia colony Grown on $4 \mathrm{mg} / \mathrm{mL}$ Geneticin has shown higher copy number compared to $2 \mathrm{mg} / \mathrm{mL}$ and $0.25 \mathrm{mg} / \mathrm{mL}$. Abad et al., (2010) also described method used for real-time PCR to quantify the integrated expression cassettes in Pichia pastoris to know the copy number.

\section{Acknowledgement}

We gratefully acknowledge the help of the National Institute of Mental Health and Neurosciences, Bangalore, for providing facilities during the initial studies and UAS Banagalore as well as Government of Karnataka for its financial support to carry out the Research.

\section{References}

Abad, S., Nahalka, J., Bergler, G., Arnold, s. A., speight, R., fotheringham, I., Nidetzky, B. and Glieder, A., 2010, Step wise engineering of a Pichia pastoris Damino acid oxidase whole cell catalyst, Microbial Cell Factories., 9:24-29

Anilionis, A., Wunner, W.H., Curtis, P.J., 1981, Structure of the glycoprotein gene in rabies virus. Nature 294, pp. 275-278.

Arellano-Sota, C., 1998, Biology and control of the vampire bat. Rev, Infect, Dis., 4:615-619.

Ashraf, S., Singh, P.K., Yadav, D.K., Shahnawaz., Mishra, S., Sawant, S.V. And Tuli, R., 2005, High level expression of surface glycoprotein of rabies virus in tobacco leaves and its immunoprotective activity in mice. J. Biotechnol., 119: 114.

Benmaamar, R., Astrayc, R, M., Wagnera, R. and Pereira, C, A., 2009, High-level expression of rabies virus glycoprotein with the RNA-based Semliki Forest Virus expression vector. J. Biotechnol., 139: 283-290

Brierley, R. A., 1998, Secretion of recombinant human insulin-like growth factor I (IGF- I). Methods in Mol. Biol., 103: 149-177

Clare, J.J., Romanos, M.A., Rayment, F.B., Rowedder, J.E., Smith, M.A., Payne, M.M., Sreekrishna, K. and Henwood, C.A., 1991, Production of mouse epidermal growth factor in yeast: highlevel secretion using Pichia pastoris strains containing multiple gene copies. Gene., 105:205-212.

Cregg, J. M., vedvick, t. S. And raschke, W. C., 1993, Recent Advances in the expression of foreign genes in Pichia pastoris. Biotechnol., 11:905-910.

Cregg, J.M., Baringer, K.J. and Hesser, A.Y., 1985, Pichia pastoris as a host system for transformations. Mol. Cell. Biol., 5:3376- 
3385.

Daly, R. and Hearn, M. T. W., 2005, Expression of heterologous proteins in Pichia pastoris: a useful experimental tool in protein engineering and production. J. Mol. Recognit., 18: 119138.

Drings, A., Jallet, C. and Chambert, B., 1999, "Is there an advantage to including the nucleoprotein in a rabies glycoprotein subunit vaccine?" Vaccine, 17, pp.15491557.

Escobar-Cifentes, E.,1998, Program for the elimination of urban rabies in Latin America. Rev. Infect. Dis., 10: 689-692.

Foley H.D., McGettigan J.P., Siler C.A., Dietzschold B., Schnell M.J., 2000, A recombinant rabies virus expressing vesicular stomatitis virus glycoprotein fails to protect against rabies virus infection. Proc Natl Acad Sci U S A., 97(26):14680-5.

Hennen, A., Hicks, J.B. and Fink, G.R., 1978, Transformation of yeast. Proc. Natl. Acad. Sci. USA., 75(4):1929-1933

Higgins, D. R. and Cregg, J. M., 1998, Introduction to Pichia pastoris. Methods in Molecular Biology 103:1-15

Higgins, D. R., Busser, K., Comiskey, J., Whittier, P. S., Purcell, T. J. and Hoeffler, J. P., 1998, Transformation of Pichia pastoris. Methods in Mol. Biol., 103: 41-53.

Kankanamage, P.J., Irie, T. and Shoji, J., 2003, "Further characterization of the rabies virus glycoprotein produced by virus-infected and G cDNA-transfected cells using a monoclonal antibody which recognizes an acid-sensitive epitope." Microbiol Immunol, 47, pp. 337-349.

Kawai, A., 1977. Transgenic activity associated with rabies virion. J Virol, 24, pp. 826-835.

Knobel, D.L., Cleaveland, S., Coleman, P.G., Fèvre, E.M., Meltzer, M.I., Miranda, M.E., Shaw, A., Zinsstag, J. and Meslin,
F.X., 2005. Re-evaluating the burden of rabies in Africa and Asia. Bull. World Health Organ., 83: 360-368.

Li, P., Anumanthan, A., Xiu-Gong, G.A.O., Ilangovan, K., Suzara, V.C., Düzgünes, N. and Renugopalakrishnan, V., 2007, Expression of recombinant proteins in Pichia pastoris. Appl Biochem Biotechnol., 142:105-124.

Liu, R., Lin, Q., Sun, Y., Lu, X., Qiu, Y., Li, Y. and Guo, X., 2009, Expression, purification, and characterization of hepatitis B virus surface antigens (HBsAg) in yeast Pichia pastoris. Appl. Biochem. Biotechnol., 158:432-444.

Mansur, M., Cabello, C., Herna' Nez, 1., Pai, J., Varas, 1., Valde, J., Terrero, Y., Hidalgo, a., Plana, 1., Besada, V., Garci, 1., Lamazares, E., Castellanos, 1. and Martínez, E., 2005, Multiple gene copy number enhances insulin precursor secretion in the yeast Pichia pastoris. Biotechnol. Letters., 27: 339-345.

Meslin, F-X., Fishbein, D.B. And Matter, H.C., 1994, Rationale and prospects for rabies elimination in developing countries. Curr. Topics Microbiol. Immunol., 187:1-26.

NASPHV (NATIONAL ASSOCIATION OF STATE PUBLIC HEALTH VETERINARIANS),2007, Inc.; Centers for Disease Control and Prevention (CDC); Council of State and Territorial Epidemiologists; American Veterinary Medical Association, Compendium of measures to prevent disease associated with animals in public settings: National Association of State Public Health Veterinarians, Inc. (NASPHV), 56: 1-14. Rombaut, B. and Jore, J.P.M., 1997, Immunogenic non-infectious polio subviral particles synthesized in Saccaromyces cerveseae. J.Gen.Virol., 78: 1829-1932

Sakamotoa, S., Ide, T., Tokiyoshi, S., Nakaoa, J., Hamadaa, F., Yamamotoa, M., 
Grosbyb, J. A., Nic, Y. and Kawai, A., 1999, Studies on the structures and antigenic properties of rabies virus glycoprotein analogues produced in yeast cells. Vaccine., 17: 205-218.

Salah, R.B., Gargouri, A., Verger, R., Gargouri,Y. and Mejdoub, H., 2009, Expression in Pichia pastoris X33 of Histagged lipase from a novel strain of Rhizopus oryzae and its mutant Asn 134 His: purification and characterization. World J. Microbiol. Biotechnol., 25:1375-1384.

Sambrook, J. and Russell R. W., 2001, Molecular cloning: a laboratory manual, 3rd ed. Cold spring, NY: cold Spring Harbor Laboratory Press.

Sambrook, J., Fritsch, E.F. and Maniatis, T., 1989, Molecular cloning: A laboratory manual, 2nd edn. Cold Spring Harbor, NY: Cold Spring Harbor Laboratory.

Schneider, M.C., Belotto, A., Adé, M.P., Hendrickx, S., Leanes, L.F., Rodrigues, M.J., Medina, G. and Correa, E., 2007, Current status of human rabies transmitted by dogs in Latin America. Cad. Saude. Publica., 23: 2049-2063.

Scorer, C. A., Clare, J. J., Mccombie, W. R., Romanos, M. A., and Sreekrishna, K., 1994,

Rapid Selection Using G418 of High Copy Number Transformants of Pichia pastoris for High-level Foreign Gene Expression. Biotechnol., 12: 181-184

Sorensen., 2010, Towards universal systems for recombinant gene expression. Microbial Cell Factories, 5: 9-27.

Su, M., Xu, T., Wanga, D., Zhou, Y., Niu, C., and Yan, W., 2009, High yield and purification of recombinant human apolipoprotein E3 in Pichia pastoris. Protein Expr. Purif., 68: 7-11.

Sudarshan, M.K., Madhusudana, S.N., Mahendra, B.J., Rao, N.S., Ashwathnarayana, D.H., Abdul Rahman, S., Meslin F.X., Lobo, D., Ravikumar, K. and Gangaboraiah., 2007, Assessing the burden of human rabies in India: results of a national multi-center epidemiological survey. Int. J. Infect. Dis., 11: 29-35.

Surgue, R.J., Fu, J., Howe, J. and Chan, Y.C., 1997, Expression of the dengue virus structural proteins in Pichia pastoris leads to the generation of virus -like particals. J.Gen.Virol.,78:1861-1866

Thill, G.P., Davis, G.R.,Stillman, C., Holtz, G., Brierly, R., Engel, M., Buckholtz, R., Kenney, J., Provow, S., Vedvick, T. and Siegel, R.S., 1990, Positive and negative effects of multicopy integrated expression vectors on protein expression in Pichia pastoris. In: Proceedings of the Sixth International Symposium on the Genetics of Microorganisms , 2: 477-490.

Wunner, W.H., Dietzschold, B., Curtisf, P.J., and Wlktor, T.J., 1983, Rabies Subunit Vaccines. J. Gen. Virol., 64: 1649-1656.

Zhang, Y.Z., Xiong, C.I., Xiao, D.I., Jiang, R.J., Wang, Z.X., Zhang, L.Z. and Fu, Z.F., 2005, Human rabies in China. Emerg. Infect. Dis., 11: 1983-1984.

Zhu, X., Wu, S. and Letchworth, G.J., 1997, Yeast-secreted bovine herpesvirus type 1 glycoprotein DNA authentic conformational structure and immunogenecity. Vaccine, 15: 679-688.

\section{How to cite this article:}

Ningaraju, T.M. and Ramanjini Gowda, P.H. 2018. Cloning and Over Expression of CVS Rabies Virus Glycoprotein Gene in Pichia pastoris by Multimeriztion. Int.J.Curr.Microbiol.App.Sci. 7(12): 1233-1255. doi: https://doi.org/10.20546/ijcmas.2018.712.154 